\title{
EKOINNOWACYJNE MODELE BIZNESU NA PRZYKŁADZIE WYBRANYCH REGIONALNYCH INSTALACJI PRZETWARZANIA ODPADÓW KOMUNALNYCH (RIPOK)
}

\begin{abstract}
Utożsamiając rozwój zrównoważony z ekorozwojem i zasadami koncepcji dobra społecznego w wymiarze strategicznym, z uwzględnieniem ekonomicznych aspektów działalności i ekologicznie efektywnych przedsięwzięć, na uwagę zasługuje sposób realizacji tej koncepcji w sektorze gospodarki odpadami. Problem ten zyskuje szczególnego znaczenia, w czasach ekorozwoju społeczeństwa i firm, gdzie świadome ekozarządzanie w podsystemach relacji z partnerami, buduje społeczności kreatorów wartości ekologicznej i komercyjnej. Celem artykułu jest identyfikacja takich innowacyjnych, holistycznych modeli biznesu w sektorze gospodarki odpadami, które są reakcją na zmiany w środowisku tworzenia wartości. Dla osiągnięcia celu, wykorzystano metody analizy źródeł wtórnych i pogłębionej analizy przypadku. Zidentyfikowany w trakcie badań model biznesu jest sposobem na tworzenie i dostarczanie wartości oraz czerpanie zysku z jej wytworzenia, co wskazuje na dualny charakter podmiotów badań oraz pełnione przez nich funkcje koordynacyjne. Innowacyjność modelu wynika z jego modyfikacji, ze względu na kluczowe czynniki budowy ekowartości, i powiązanie jego elementów w nowatorski sposób oraz usieciowienie działań, jak to ma miejsce w przypadku badanych podmiotów sektora gospodarki odpadami. W ramach realizowanego ekoinnowacyjnego modelu biznesu, w strukturach relacji pomiędzy podmiotami, w środowisku etyki międzypokoleniowej, ekonomii umiaru, ekoświadomości i ekoefektywności, firmy realizują zasady koncepcji synergicznych ekowartości, marketingu integralnego, relacyjnego i społecznego w strategicznym horyzoncie działania. Cztery podsystemy modelu: technologiczny, społeczny, wewnątrzorganizacyjny i instytucjonalny, osadzone są w systemie integralnych relacji podmiotów sektora i ich interesariuszy. Wielowymiarowość modelu świadczy o jego holistycznym charakterze.
\end{abstract}

Słowa kluczowe: ekoinnowacyjny model biznesu, biznes ekologiczny, rozwój zrównoważony, ekomodel, ekowartość.

\section{WPROWADZENIE}

Utożsamiając ekoinnowacyjny model biznesu z integralnym rozwojem zrównoważonym podmiotu gospodarczego i dobrem społecznym w wymiarze strategicznym, z uwzględnieniem ekonomicznych aspektów działalności, na uwagę zasługuje sposób realizacji tej koncepcji, przez efektywną gospodarkę odpadami w Regionalnych Instala-

\footnotetext{
${ }^{1}$ Dr Izabela Sztangret, Wydział Zarządzania, Katedra Polityki Rynkowej i Zarządzania Marketingowego, Uniwersytet Ekonomiczny w Katowicach, e-mail: izabela.sztangret@ue.katowice.pl 2 Mgr inż. Sławomir Sobociński, MASTER - Odpady i Energia Sp. z o.o. Tychy.
} 
cjach Przetwarzania Odpadów Komunalnych (RIPOK), w województwie śląskim. Problem ten nabiera szczególnego znaczenia w dynamicznym otoczeniu funkcjonowania podmiotów, warunkowanym zmianami społecznymi (zgodnie z paradygmatem tzw. godnego społeczeństwa, etyki międzypokoleniowej, share consumption), ekonomicznymi (ekonomii umiaru, dekonsumpcji, jako odpowiedzi na nadmierny konsumpcjonizm), środowiskowymi (ekologizacji i ekoefektywności, w opozycji do „eksploatacji zasobów bez granic").

Celem artykułu jest identyfikacja i charakterystyka modelu biznesu, podmiotów sektora gospodarki odpadami, będącego reakcją na zmiany otoczenia.

Przypuszcza się, że ekoinnowacyjne modele biznesu podmiotów gospodarki odpadami noszą charakter kumulatywny i holistyczny, obejmują bowiem synergiczne podsystemy budowy ekowartości $w$ integralnych relacjach pomiędzy podmiotami, oraz osadzone są w zaangażowanych technologiach.

W opracowaniu wykorzystano wyniki badań, przeprowadzonych metodą analizy źródeł wtórnych, tj. branżowych czasopism specjalistycznych, w tym wywiadów sponsorowanych, oraz publikacji organizacji branżowych. Zastosowano badania metodą pogłębionej analizy przypadków, na próbie celowo dobranych podmiotów, posiadającymi status instalacji regionalnej (tzw. RIPOK), będących liderami i reprezentującymi cztery regiony województwa śląskiego. W trakcie badań przeprowadzono wywiady bezpośrednie z menedżerami firm i ich kooperantami.

\section{MODEL BIZNESU - DEFINICJA KATEGORII BADAWCZEJ}

W literaturze przedmiotu powszechnie przyjmuje się, iż pojęcie „,model biznesu” po raz pierwszy zostało użyte w artykule naukowym przez R. Bellmana i C. Clarka w 1957 roku. G. Jones natomiast umieścił ten termin jako pierwszy w tytule artykułu oraz abstrakcie z 1960 roku $^{3}$.

Model biznesu opisuje przesłanki stojące za sposobem, w jaki organizacja tworzy i dostarcza wartość oraz czerpie zysk z tej wytworzonej wartości ${ }^{4}$. Według Portera model biznesowy jest opisem działalności przedsiębiorstwa, która zapewnia mu zyski. Sprowadza się to do określenia roli organizacji w łańcuchu wartości, w jakim działa. W kompleksowym ujęciu chodzi o metodę przyjętą przez firmę, przez realizację, której będzie ona powiększać i wykorzystywać zasoby tak, aby oferować klientom większą wartość od konkurencji. Dzięki temu przedsiębiorstwo osiągnie wyższe zyski, a może nawet uzyska i utrzyma trwałą przewagę konkurencyjną. A. Afuaha twierdzi, że model biznesowy jest zespołem działań, które firma prowadzi, metod i czasu ich przeprowadzania, używając do tego zasobów, aby dać korzyści klientowi, a sobie zapewnić zysk ${ }^{5}$. K. Obłój definiuje model biznesowy, jako ,połączenie koncepcji strategicznej firmy i technologii jej praktycznej realizacji, rozumianej jako budowa łańcucha wartości pozwalającego na skuteczną

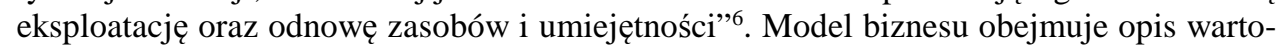

\footnotetext{
${ }^{3}$ A. Osterwalder, Y. Pigneur, C.L. Tucci, Clarifying Business Models: Origin, Present and Future of the Concept, ,Communications of the Association for Information Systems” 2005, Vol. 15.

4 A. Osterwalder, Y. Pigneur, Business Model Generation: A Handbook for Visionaries, Game Changers and Challengers, New Jersey 2010, s. 14.

5 A. Afuah, Business models. A Strategic Management Approach, McGraw-Hill Irwin, 2004, s. 2.

${ }^{6}$ K. Obłój, Tworzywo skutecznych strategii, Warszawa 2002, s. 98.
} 
ści oferowanej przez przedsiębiorstwo grupie lub grupom klientów, wraz z określeniem podstawowych zasobów, procesów (działań), a także relacji zewnętrznych tego przedsiębiorstwa, służących tworzeniu, oferowaniu oraz dostarczaniu tej wartości i zapewniających przedsiębiorstwu konkurencyjność w danej dziedzinie oraz umożliwiających zwiększanie jego wartości ${ }^{7}$. Podejście to podziela B. Nogalski, który stwierdza: „Model biznesu, jako ogólna koncepcja formułuje ramy logiki prowadzenia biznesu i takich jego cech jak innowacyjność, konkurencyjność". Obejmuje zatem opis wartości oferowanej klientom, podstawowych zasobów, działań oraz relacji z partnerami, które służą tworzeniu tej wartości oraz zapewniają przedsiębiorstwu konkurencyjność ${ }^{8}$. Wszystkie definicje wskazują, że model biznesu:

- należy do pojęć „rozwijających się”;

- określa sposób, w jaki kreowana jest wartość;

- wyraźnie akcentuje holistyczne podejście do organizacji oraz jej funkcjonowania;

- wskazuje znaczącą rolę organizacji działań przedsiębiorstwa.

Innowacyjny model biznesu (Business Model Innovation - BMI) przybiera swój charakter, gdy dwa lub więcej jego elementów są przeprojektowane tak, by dostarczać wartość w nowy sposób 9 . Taki innowacyjny model biznesu może powstać na wiele sposobów, m.in. poprzez zmianę elementów modelu biznesu i powiązanie działań w nowatorski sposób (np. nowy sposób realizacji podstawowych procesów z uwzględnieniem zasad koncepcji $3 \mathrm{R}^{10}$ ) lub też przez usieciowienie działalności, przykładowo w wyniku integratywnych relacji podmiotów zasileń i klientów komercyjnych, na rzecz budowy ekowartości.

Projektowanie biznesu ekologicznego, jakim bez wątpienia jest gospodarka odpadami, musi dążyć do synergii efektu ekonomiczno-biznesowego z aspektem środowiskowym tegoż przedsięwzięcia. Ewaluacja gospodarki odpadami w Polsce na przełomie ostatnich kilkunastu lat, doprowadziła do wprowadzenia nowoczesnych technologii ekologicznych w procesie przetwarzania odpadów komunalnych, co nadaje modelowi znamiona innowacyjnego. Ponadto, ekoinnowacyjność modelu biznesu coraz częściej odnajduje swój wyraz w świadomości społeczeństwa, w aspekcie celowości wydatkowania określonych środków finansowych na działania podejmowane, na rzecz efektywnej gospodarki odpadami. Stąd, w kontekście specyfiki sektora gospodarki odpadami, model biznesu tych podmiotów nosi charakter holistyczny, bo dotyczy podsystemów ekoinnowacji organizacyjnych, instytucjonalnych, technologicznych i społecznych oraz kumulacji efektu

7 T. Gołębiowski, T.M. Dudzik, M. Lewandowska, M. Witek-Hajduk M., Modele biznesu polskich przedsiębiorstw, Warszawa 2008, s. 57.

8 B. Nogalski, Modele biznesu jako narzędzie reorientacji strategicznej przedsiębiorstw, „Master of Business Administration" 2009, nr 2, s. 45.

9 Z. Lindgardt, M. Reeves, G. Stalk, M.S. Deimler, Business Model Innovation: When the Game Gets Tough, Change the Game. The Boston Consulting Group, 2009, s. 1-2, http://www.bcg.com/ documents/file36456.pdf, (dostęp: 9.02.2014 r.).

${ }^{10}$ Szerzej na ten temat: I. Sztangret, Sustainable Development Through Knowledge Management on the Example of Public Utilities Enterprise in IT Environment, "Business and Management Studies" 2016, Vol. 2, No. 1, March, s. 65-72. 
w ekowartość, warunkującą dobrostan w długiej perspektywie czasowej ${ }^{11}$. Fakt ten nadaje modelowi wymiar strategiczny.

\section{METODY BADAŃ}

W pracy wykorzystano metody badań konceptualnych oraz jakościowych badań empirycznych (case stady) ${ }^{12}$. Dokonano analizy literatury przedmiotu oraz badań opartych na źródłach wtórnych i pierwotnych.

Tabela 1. Podstawowe informacje na temat przeprowadzonych badań

\begin{tabular}{|c|l|}
\hline Specyfikacja & \multicolumn{1}{c|}{ Cechy charakterystyczne } \\
\hline Technika badań & $\begin{array}{l}\text { Krytyczna analiza literatury i czasopism, analiza stron interneto- } \\
\text { wych, analiza wywiadów sponsorowanych, wywiady bezpośrednie }\end{array}$ \\
\hline Dobór próby & Dobór celowy jednostek typowych \\
\hline \multirow{2}{*}{ Wielkość próby } & 4 liderów sektora gospodarki odpadami \\
\cline { 2 - 2 } & Ponad 10 branżowych stron internetowych \\
\hline Zasięg geograficzny & Zasięg regionalny \\
\hline Zakres czasowy & $2014-2016$ \\
\hline
\end{tabular}

Źródło: opracowanie własne.

Dla analizy w aspekcie ekoinnowacyjnych rozwiązań, jak i podejścia środowiskowego w firmach zapewniających mechaniczno-biologicznego przetwarzanie odpadów komunalnych mających status RIPOK, wybrano po jednej instalacji z każdego regionu określonego w WPGO województwa śląskiego (tabela 2).

Wśród podmiotów badań znalazły się:

- Częstochowskie Przedsiębiorstwo Komunalne Sp. z o.o. z siedzibą w Sobuczynie, które jest spółką gminną ze 100-procentowym udziałem Miasta Częstochowa. Zarządzana przez CzPK Sp. z o.o. instalacja w zakresie przetwarzania odpadów komunalnych posiadająca status RIPOK, jest instalacją zapewniającą mechanicznobiologiczne przetwarzanie zmieszanych odpadów komunalnych i wydzielanie ze

${ }^{11}$ Taka interpretacja ekoinnowacyjnego modelu biznesu koresponduje z koncepcją zrównoważonego rozwoju, która zdefiniowana jest jako taki rozwój społeczno-gospodarczy, w którym następuje proces integrowania działań politycznych, gospodarczych i społecznych, z zachowaniem równowagi przyrodniczej oraz trwałości podstawowych procesów przyrodniczych, w celu zagwarantowania możliwości zaspokajania podstawowych potrzeb poszczególnych społeczności lub obywateli zarówno współczesnego pokolenia, jak i przyszłych pokoleń. Ustawa z dnia 27 kwietnia 2001 r. Prawo ochrony środowiska (Dz.U. z 2001 r., nr 62, poz. 627 ze zm.).

${ }^{12}$ Zastosowanie metody wydaje się zasadne ze względu na to, że: (1) badania dotyczą współczesnych, dynamicznych zjawisk oraz tworzącej się wiedzy o tych zjawiskach; (2) dotyczą badania realnych kontekstów tych zjawisk, przy dużej niejasności granic między ich kontekstami a samymi zjawiskami; (3) przedmiot badań jest zbyt skomplikowany, aby wyjaśnić związki przyczynowo-skutkowe za pomocą metody sondażu czy eksperymentu. Ch. Perry, Case Research In Marketing. "The Marketing Review" 2001, No 1, p. 305 [w:] Zarzadzanie marketingowe. Koncepcje marketingu a praktyki zarzadzania. Aspekty teoretyczne i badawcze, red. T. Żabińska, L. Żabiński, Katowice 2007, s. 83. 
zmieszanych odpadów komunalnych frakcji nadających się w całości lub w części do odzysku o wydajności $95000 \mathrm{Mg} /$ rok;

- Miejskie Przedsiębiorstwo Gospodarki Komunalnej Spółka z o.o. w Katowicach. Zarządzana przez MPGK Katowice, jest instalacją zapewniającą mechaniczno-biologiczne przetwarzanie zmieszanych odpadów komunalnych i wydzielanie ze zmieszanych odpadów komunalnych frakcji nadających się w całości lub w części do odzysku o wydajności $72000 \mathrm{Mg} / \mathrm{rok}$;

- Przedsiębiorstwo Produkcyjno-Handlowo-Usługowe „KOMART” sp. z o.o. Zarządzana przez PHU „KOMART” jest instalacją zapewniającą mechaniczno-biologiczne przetwarzanie zmieszanych odpadów komunalnych i wydzielanie ze zmieszanych odpadów komunalnych frakcji nadających się w całości lub w części do odzysku o wydajności $95000 \mathrm{Mg} / \mathrm{rok}$;

- MASTER Odpady i Energia Sp. z o.o. jest firmą posiadającą nowoczesną instalację zapewniającą mechaniczno-biologiczne przetwarzanie zmieszanych odpadów komunalnych i wydzielanie ze zmieszanych odpadów komunalnych frakcji nadających się w całości lub w części do odzysku o wydajności 70000 Mg/rok.

Tabela 2. Charakterystyka wybranych RIPOK z Wojewódzkiego planu gospodarki odpadami (WPGO) województwa śląskiego

\begin{tabular}{|l|c|c|c|c|}
\cline { 2 - 5 } & $\begin{array}{c}\text { Częstochowskie } \\
\text { Przedsiębiorstwo } \\
\text { Komunalne } \\
\text { Sp. z o.o. } \\
\text { Sobuczyn }\end{array}$ & $\begin{array}{c}\text { Miejskie Przed- } \\
\text { siębiorstwo Go- } \\
\text { spodarki Komu- } \\
\text { nalnej Sp. z o.o. } \\
\text { Katowice }\end{array}$ & $\begin{array}{c}\text { PPHU KOMART } \\
\text { Sp. z o.o. Knurów }\end{array}$ & $\begin{array}{c}\text { MASTER - } \\
\text { Odpady i Energia } \\
\text { Sp. z o.o. Tychy }\end{array}$ \\
\hline $\begin{array}{l}\text { Region } \\
\text { w WPGO } \\
\text { województwa } \\
\text { Śląskiego }\end{array}$ & I & II & III & IV \\
\hline $\begin{array}{l}\text { Data nadania } \\
\text { statusu RIPOK }\end{array}$ & $24-$-sie-12 & $24-$ sie-12 & $24-$ sie-12 & $16-$-mar-15 \\
\hline $\begin{array}{l}\text { Przepustowość } \\
\text { części mecha- } \\
\text { nicznej zakładu } \\
\text { dla odpadów } \\
\text { komunalnych } \\
\text { zmieszanych }\end{array}$ & 95000 & 72000 & 95000 & 70000 \\
\hline $\begin{array}{l}\text { Przepustowość } \\
\text { części biolo- } \\
\text { gicznej zakładu }\end{array}$ & 45000 & 30000 & 26000 & 30000 \\
\hline $\begin{array}{l}\text { Kompostowa- } \\
\text { nie odpadów } \\
\text { zielonych }\end{array}$ & Tak & Tak & Nie & Tak \\
\hline $\begin{array}{l}\text { Fermentacja } \\
\text { metanowa }\end{array}$ & Nie & Nie & Tak \\
\hline
\end{tabular}

Źródło: Plan gospodarki odpadami dla województwa śląskiego 2014 - uchwała nr IV/25/1/2012 Sejmiku Województwa Śląskiego z dnia 24 sierpnia 2012 roku oraz uchwała nr V/6/21/2015 Sejmiku Województwa Śląskiego z dnia 16 marca 2015 r. 
Analizując ww. podmioty brano pod uwagę kluczowe czynniki budowy ekowartości, w opinii badanych podmiotów, takie jak:

- sposób sortowania odpadów;

- stan zamaszynowienia instalacji;

- sposób zagospodarowania frakcji podsitowej 0-80 mm;

- oddziaływanie jednostki na środowisko i najbliższe otoczenie.

\section{4. ŚRODOWISKO ROZWOJU EKOINNOWACYJNYCH MODELI BIZNESU W SEKTORZE GOSPODARKI ODPADAMI}

Gospodarka odpadami należy do zadań własnych gminy zapisanych w ustawie o utrzymaniu czystości i porządku w gminie i przez wiele lat była pewnego rodzaju biznesem prowadzonym praktycznie wyłącznie przez podmioty komunalne. Zmiany systemowe, akces do struktur UE i związane z tym rozluźnienie przepisów prawnych związanych z udzielaniem koncesji na prowadzenie działalności „odpadowej”, doprowadziły do rozwoju podmiotów zajmujących się tą częścią gospodarki, zmieniając podejście z czysto komunalnego na model biznesowo-środowiskowy w zarządzaniu odpadem. Obecnie gospodarką odpadami zajmują się również firmy prywatne, w tym duże koncerny, które tę część rynku przejęły w dużym zakresie po zmianach gospodarczych w naszym kraju. Rozwój branży determinowany jest głównie przepisami prawnymi, które narzucają określone wymagania związane $\mathrm{z}$ postępowaniem $\mathrm{z}$ odpadami.

Schemat postępowania $\mathrm{z}$ odpadami po zmianie ustawy o utrzymaniu czystości i porządku w gminach oraz ustawy o odpadach, obowiązujący od 1 lipca 2013 roku zilustrowany jest na rys. 1. Istotnym elementem jest fakt, że to gminy zostały podmiotem, który przejmuje odpad od mieszkańca i określa dalszą drogę postępowania z odpadem. Dla gmin, które są właścicielami podmiotów zajmujących się zagospodarowaniem odpadami, nastąpił pewnego rodzaju dyskomfort w podejściu nadzoru właścicielskiego do ww. jednostek w konfrontacji z dbałością o interesy mieszkańców, ponieważ gmina w tym wypadku jest właścicielem i klientem tej jednostki.

W założeniach wynikających z dyrektywy 2008/98/WE oraz ustawy o odpadach z dnia 14 grudnia 2012 r. sposób postępowania z odpadami jest określony hierarchicznie poprzez:

- zapobieganie powstawaniu odpadów;

- przygotowanie do ponownego użycia;

- recykling;

- inne procesy odzysku;

- unieszkodliwianie ${ }^{13}$.

W zapisach przytoczonej ustawy z dnia 14 grudnia 2012 roku wprowadzono pojęcie Regionalnych Instalacji Przetwarzania Odpadów Komunalnych, określając minimalne wymagania dla powstania takiego podmiotu. Po zmianie ustawy o odpadach z dnia 22 stycznia 2015 określono, iż regionalną instalacją do przetwarzania odpadów komunalnych jest zakład zagospodarowania odpadów, o mocy przerobowej wystarczającej do przyjmowania i przetwarzania odpadów z obszaru zamieszkanego, co najmniej przez 120 tys. mieszkańców, spełniający wymagania najlepszej dostępnej techniki, o której mowa w art. 207 ustawy z dnia 27 kwietnia 2001 r. - Prawo ochrony środowiska, lub technologii,

${ }^{13}$ Art. 17 ustawy z dnia 14 grudnia 2012 r. o odpadach (Dz.U. z 2013 r., poz. 21). 


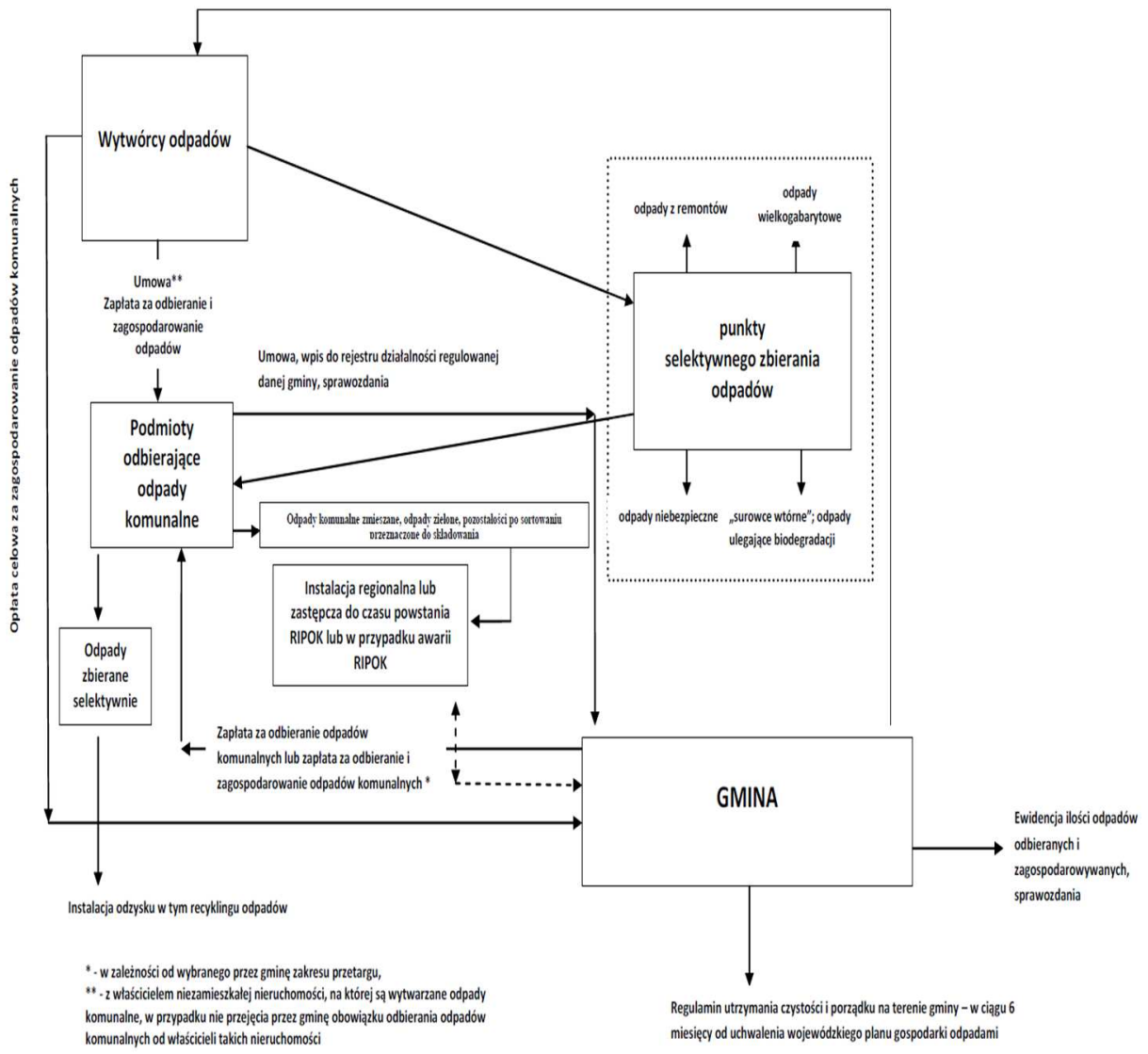

Rys. 1. Schemat postępowania z odpadami po 1 lipca 2013 roku

Źródło: Plan gospodarki odpadami dla województwa śląskiego 2014 - uchwała nr IV/25/1/2012 Sejmiku Województwa Śląskiego z dnia 24 sierpnia 2012 roku.

o której mowa w art. 143 tej ustawy, w tym wykorzystujący nowe dostępne technologie przetwarzania odpadów lub zapewniający:

- mechaniczno-biologiczne przetwarzanie zmieszanych odpadów komunalnych i wydzielanie ze zmieszanych odpadów komunalnych frakcji nadających się w całości lub w części do odzysku lub

- przetwarzanie selektywnie zebranych odpadów zielonych i innych bioodpadów oraz wytwarzanie z nich produktu o właściwościach nawozowych lub środków wspomagających uprawę roślin, spełniających wymagania określone w przepisach odrębnych, lub materiału po procesie kompostowania lub fermentacji dopuszczonego do odzysku w procesie odzysku R10, spełniającego wymagania określone w przepisach wydanych na podstawie art. 30 ust. 4, lub

- składowanie odpadów powstających w procesie mechaniczno-biologicznego przetwarzania zmieszanych odpadów komunalnych oraz pozostałości z sortowania odpadów komunalnych o pojemności pozwalającej na przyjmowanie przez okres nie 
krótszy niż 15 lat odpadów w ilości nie mniejszej niż powstająca w instalacji do mechaniczno-biologicznego przetwarzania zmieszanych odpadów komunalnych.

Regionalne Instalacje Przetwarzania Odpadów Komunalnych w województwie śląskim funkcjonują w czterech regionach gospodarki odpadami (rys. 2). Ustawa o odpadach daje możliwość podziału województw w wojewódzkich planach gospodarki odpadami (WPGO) na regiony pod warunkiem, że spełnią minimalne wymogi określone w art. 35 pkt 5 ustawy, tj. region gospodarki odpadami komunalnymi stanowi obszar sąsiadujących ze sobą gmin liczących łącznie co najmniej 150 tys. mieszkańców i obsługiwany jest przez instalacje, o których mowa w ust. 6. Regionem gospodarki odpadami komunalnymi może być również obszar gminy liczącej powyżej 500 tys. mieszkańców.

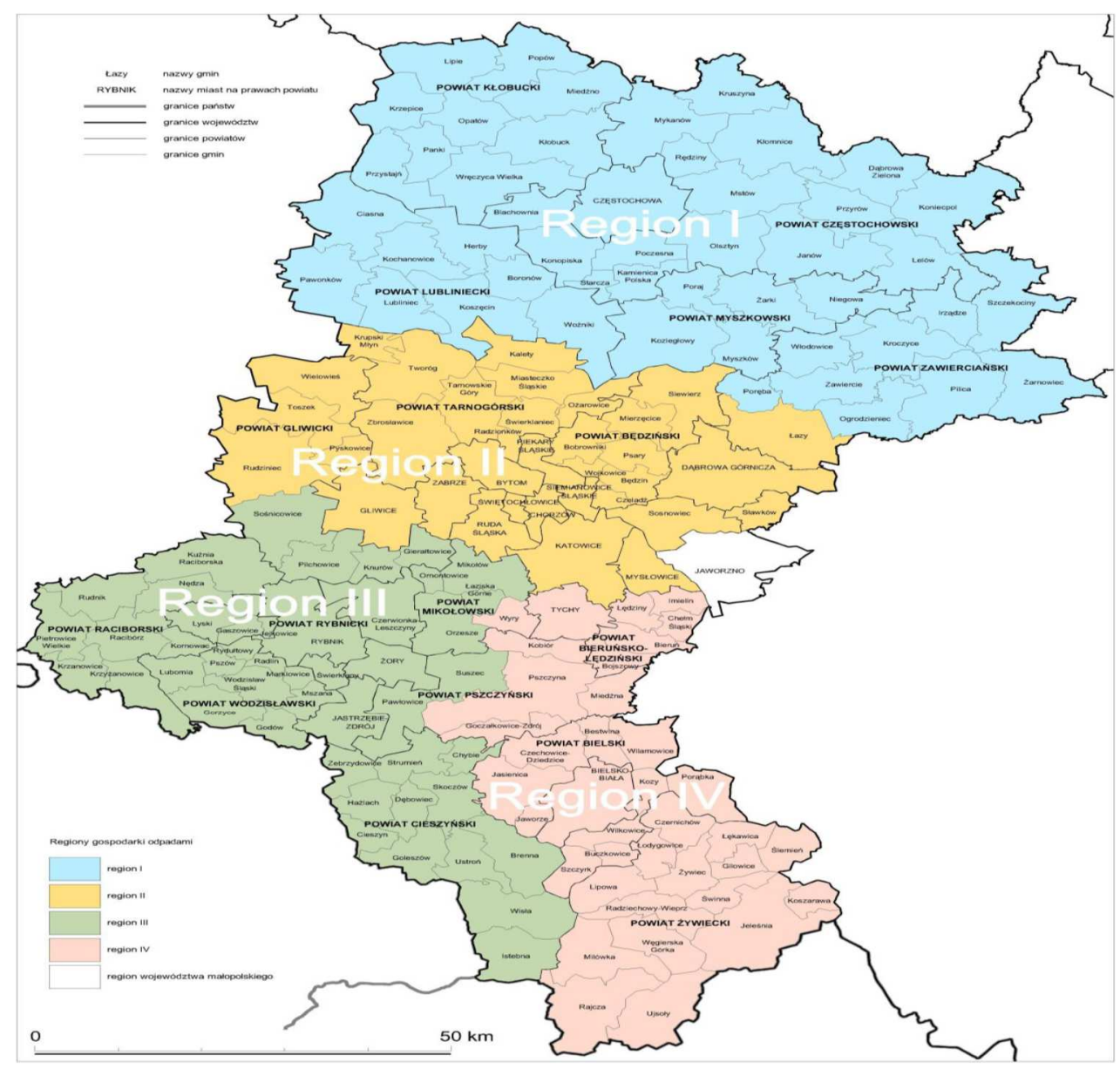

Rys. 2. Mapa podziału województwa śląskiego na cztery regiony gospodarki odpadami

Źródło: Plan gospodarki odpadami dla województwa śląskiego - uchwała nr IV/25/1/2012 Sejmiku Województwa Śląskiego z dnia 24 sierpnia 2012 roku. 
Nowe regulacje zapisane w zmianie do ustawy z dnia 22 stycznia 2015 roku o odpadach określają, że region gospodarki odpadami komunalnymi może obejmować sąsiadujące ze sobą gminy z różnych województw, jeżeli przewidują to wojewódzkie plany gospodarki odpadami tych województw ${ }^{15}$. Kolejnym $\mathrm{z}$ istotnych zapisów tejże ustawy jest wprowadzenie pojęcia instalacji ponadregionalnej, którą może być spalarnia odpadów komunalnych o mocy przerobowej wystarczającej do przyjmowania i przetwarzania zmieszanych odpadów komunalnych zebranych z obszaru zamieszkanego co najmniej przez 500 tys. mieszkańców, spełniająca wymagania najlepszej dostępnej techniki, zwana ,ponadregionalną spalarnią odpadów komunalnych".

\section{SUBPROCESY BUDOWY EKOWARTOŚCI PRZEZ PRZEDSIEBIORSTWA SEKTORA GOSPODARKI ODPADAMI O STATUSIE RIPOK}

\subsection{Sortowanie i zamaszynowienie $w$ instalacjach}

Sposób sortowania odpadów jest ściśle związany z inną analizowaną kategorią, tj. ilością urządzeń w danej instalacji. Zarządzający zakładami w Częstochowie jak i w Knurowie postawili w dużej mierze na tzw. czynnik ludzki. Odpady trafiające do wymienionych instalacji po wydzieleniu frakcji podsitowej $0-80 \mathrm{~mm}$, są głównie segregowane przez pracowników. Wydziela się w ten sposób frakcje surowcowe nadające się do recyklingu takie jak tworzywa typu pet, chemia gospodarcza i spożywcza, folia, papier, metale oraz opakowania tetra-pak. Frakcja 0-80, która według zapisów rozporządzenia Ministra Środowiska z dnia 11 września 2012 r. w sprawie mechaniczno-biologicznego przetwarzania zmieszanych odpadów komunalnych ${ }^{16}$, zostaje w procesie mechanicznego przetwarzania zmieszanych odpadów komunalnych wydzielona i jest traktowana jako frakcja ulegająca biodegradacji oznaczona kodem 1912 12, wymagająca zastosowania procesów biologicznego przetwarzania, przez które rozumie się procesy prowadzone $\mathrm{w}$ warunkach tlenowych lub beztlenowych $\mathrm{z}$ udziałem mikroorganizmów, w wyniku których następują zmiany właściwości fizycznych, chemicznych lub biologicznych odpadów. W katowickim zakładzie proces sortowania zmechanizowano. Zastosowano już urządzenia do wydzielania poszczególnych surowców oraz frakcji energetycznej z odpadów. Jednak niekwestionowanym liderem w zamaszynowieniu jest Zakład Kompleksowego Zagospodarowania Odpadów Komunalnych w Tychach. Zarządzający spółką Master postawili na pełną ekoinnowacyjność rozwiązań w zakresie gospodarki odpadami. W tyskim zakładzie zastosowano praktycznie wszystkie $\mathrm{z}$ możliwych w danym czasie rozwiązań służących do efektywnego sortowania odpadów. Głównym elementem, który wyróżnia tyski zakład jest zastosowanie siedmiu separatorów opto-pneumatycznych, które na podstawie rozpoznawania właściwości fizyko-chemicznych odpadów są w stanie wydzielić poszczególne surowce ze skutecznością powyżej $80 \%$.

\subsection{Zagospodarowanie frakcji $0-80 \mathrm{~mm}$}

Wspomniane, lecz nieobowiązujące od 23 stycznia 2016 roku rozporządzenie dotyczące mechaniczno-biologicznego przetwarzania odpadów określało sposób zagospoda-

\footnotetext{
${ }^{15}$ Ustawa z dnia 15 stycznia 2015 r. o zmianie ustawy o odpadach oraz niektórych innych ustaw (Dz.U. z 2015 r., poz. 122).

16 Rozporządzenie Ministra Środowiska z dnia 11 września 2012 r. w sprawie mechaniczno-biologicznego przetwarzania zmieszanych odpadów komunalnych (Dz.U. z 2012 r., poz. 1052).
} 
rowania frakcji biologicznej wydzielonej z odpadów komunalnych, jaką jest frakcja 0-80 $\mathrm{mm}, \mathrm{z}$ możliwością zastosowania dwóch procesów, tj. w warunkach tlenowych oraz beztlenowych. Procesy biologicznego przetwarzania odpadów w warunkach tlenowych prowadzi się zgodnie ze ściśle określonymi wymaganiami. Odpady wydzielone, jako frakcja 0-80 mm, są przetwarzane z przerzucaniem odpadów przez okres od 8 do 12 tygodni łącznie, w tym przez co najmniej pierwsze 2 tygodnie proces odbywa się w zamkniętym reaktorze lub w hali, $\mathrm{z}$ aktywnym napowietrzaniem, $\mathrm{z}$ zabezpieczeniem uniemożliwiającym przedostawanie się nieoczyszczonego powietrza procesowego do atmosfery, do czasu osiągnięcia wartości AT4 (rozumianej jako aktywność oddychania - parametr wyrażający zapotrzebowanie w tlen przez próbkę odpadów w ciągu 4 dni) poniżej $20 \mathrm{mg}$ O2/g suchej masy. W procesach biologicznego przetwarzania odpadów w warunkach beztlenowych ww. odpady są poddawane stabilizacji beztlenowej w procesie dwustopniowym:

- w pierwszym stopniu fermentacji mezofilowej, przez co najmniej 20 dni lub fermentacji termofilowej, przez co najmniej 12 dni, w drugim stopniu stabilizacji tlenowej $\mathrm{w}$ zamkniętym reaktorze lub $\mathrm{w}$ hali, $\mathrm{z}$ aktywnym napowietrzaniem, $\mathrm{z}$ zabezpieczeniem uniemożliwiającym przedostawanie się nieoczyszczonego powietrza procesowego do atmosfery, przez okres co najmniej 2 tygodni;

- w drugim stopniu stabilizacji tlenowej dopuszcza się stabilizację w pryzmach na otwartym terenie, napowietrzanych przez przerzucanie odpadów, co najmniej raz w tygodniu, przez okres co najmniej 3 tygodni.

W instalacjach częstochowskiej, katowickiej oraz w Knurowie prowadzi się procesy tlenowe w celu zagospodarowania frakcji podsitowej 0-80 $\mathrm{mm}$. Zastosowano bioreaktory, w których poprzez napowietrzanie i nawadnianie uzyskuje się odpowiednie warunki do prawidłowej stabilizacji odpadów. W tyskiej spółce Master i w tym przypadku postawiono na jak najefektywniejsze przetworzenie frakcji podsitowej. W pierwszej kolejności frakcję biodegradowalną wykorzystuje się w procesie beztlenowej fermentacji do produkcji biogazu, z którego poprzez spalanie w agregatach kogeneracyjnych wytwarza się energię elektryczną i cieplną na potrzeby zakładu. Po procesie beztlenowym, przefermentowany odpad poddawany jest procesom tlenowym w specjalnych komorach kompostujących.

\section{3. Środowisko naturalne i najbliższe otoczenie działania}

Wymagania dotyczące prowadzenia procesów tlenowych zagospodarowania frakcji biodegradowalnej nakładają obowiązek zabezpieczenia sposobu prowadzenia procesu, aby uniemożliwić przedostawanie się nieoczyszczonego powietrza procesowego do atmosfery. W analizowanych jednostkach proces oczyszczania powietrza jest prowadzony poprzez urządzenia biofiltrów, których zadaniem jest skuteczne oczyszczenie powietrza poprocesowego. W tyskim zakładzie zastosowano dwuetapowy sposób oczyszczania powietrza. W pierwszej kolejności powietrze jest płukane w specjalnych skruberach, gdzie poprzez dozowanie kwasu siarkowego wytrąca się amoniak z powietrza, a następnie powietrze przechodzi przez złoże biologiczne. Istotnym elementem oddziaływania na otoczenie jest również sposób prowadzenia procesów stabilizacji tlenowej odpadów po procesach kompostowania. Ustawodawca dopuszcza możliwość prowadzenia procesu na zewnątrz poprzez pryzmowanie i okresowe przerzucanie odpadów. Powoduje to możliwości emisji odorów do najbliższego otoczenia. W tyskim zakładzie, jako jedynym, wszystkie procesy biologicznego przetwarzania odpadów prowadzi się w zamkniętych pomieszczeniach, aby uniknąć wydostawaniu się powietrza procesowego na zewnątrz. 


\section{EKOINNOWACYJNY MODELU BIZNESU W BADANYM SEKTORZE}

Holistyczny charakter ekoinnowacyjnego modelu biznesu wyraża się integracją podsystemów ekoinnowacji o charakterze technologicznym, społecznym, organizacyjnym i instytucjonalnym, na rzecz budowy synergicznej ekowartości (rys. 3).

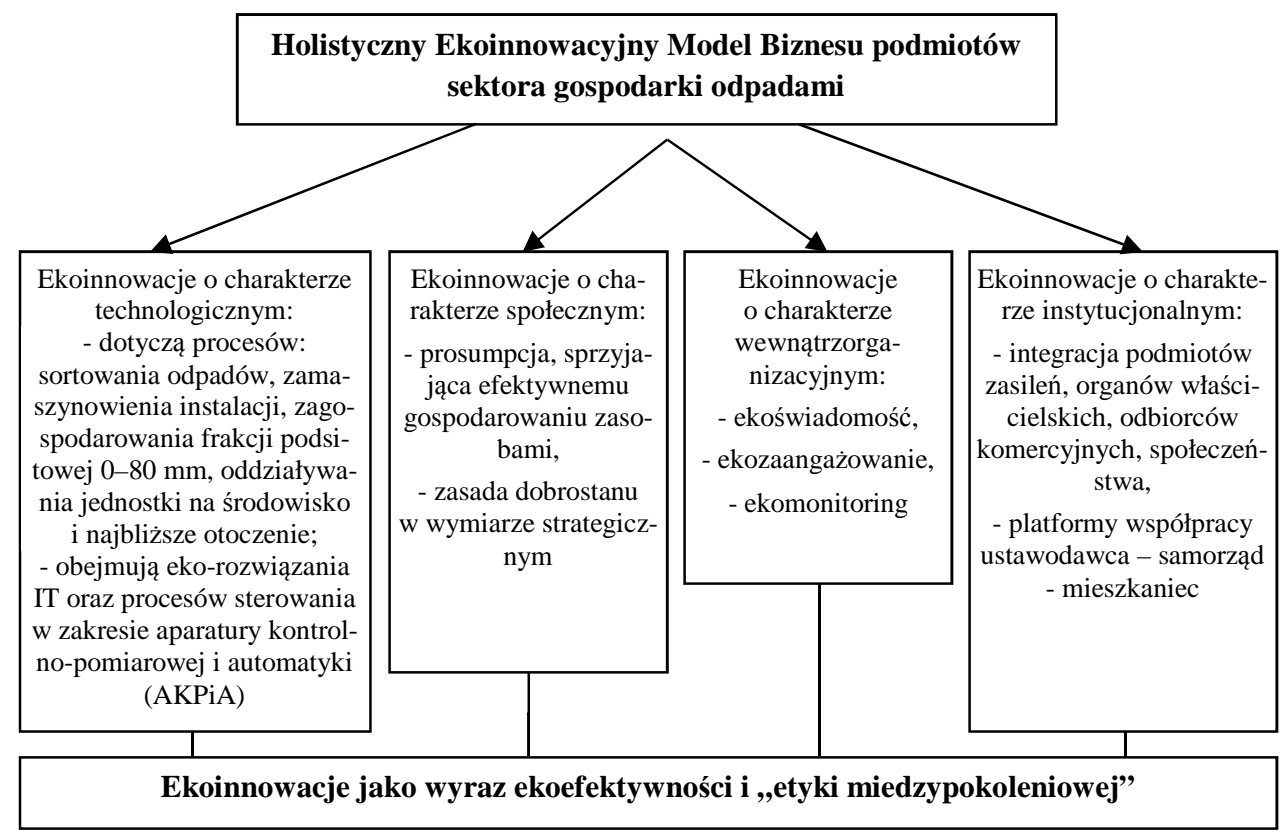

Rys. 3. Holistyczny Ekoinnowacyjny Model Biznesu podmiotów sektora gospodarki odpadami, ujęcie przedmiotowe

Źródło: opracowanie własne.

Cztery podsystemy Modelu osadzone są w systemie integralnych relacji podmiotów strony wytwarzania odpadów, zarządzania strumieniami odpadów i odbioru (transportu) oraz komercyjnymi odbiorcami odzysku i społeczeństwem. Umiejętne aktywizowanie tych podmiotów, budujące świadomość ekologiczną, postawy prosumenckie i satysfakcję z zaangażowania, co daje efekt/reakcję zwrotną. Świadomość wytwórcy odpadów w kontekście sposobu przetworzenia wytwarzanego przez niego odpadu oraz skutków, jakie powstają z niewłaściwej gospodarki odpadami często przekładają się na zmianę podejścia do odpadu. Efektem jest większa i dokładniejsza selekcja odpadu u źródła, która przekłada się na skuteczniejszą pracę instalacji do przetwarzania odpadów oraz na efektywniejsze procesy odzysku.

W związku z powyższym, badane przedsiębiorstwa pełnią rolę tzw. promotora relacji opartych na trzech zasadach ekoefektywności i etyki międzypokoleniowej, w systemie relacji z podmiotami reprezentującymi środowisko kooperantów sieciowych i klientów, dla wykreowania ekowartości oraz warunków równowagi pomiędzy dobrostanem społecznym, środowiskowym i efektem ekonomicznym, w długiej perspektywie czasowej, 
którego powodzenie zależy również od umiejętnego zarządzania wiedzą w tym ekosystemie, budującej świadomość, aktywne postawy prosumenckie wytwórcy opadów i mieszkańca oraz satysfakcję z zaangażowania (rys. 4).

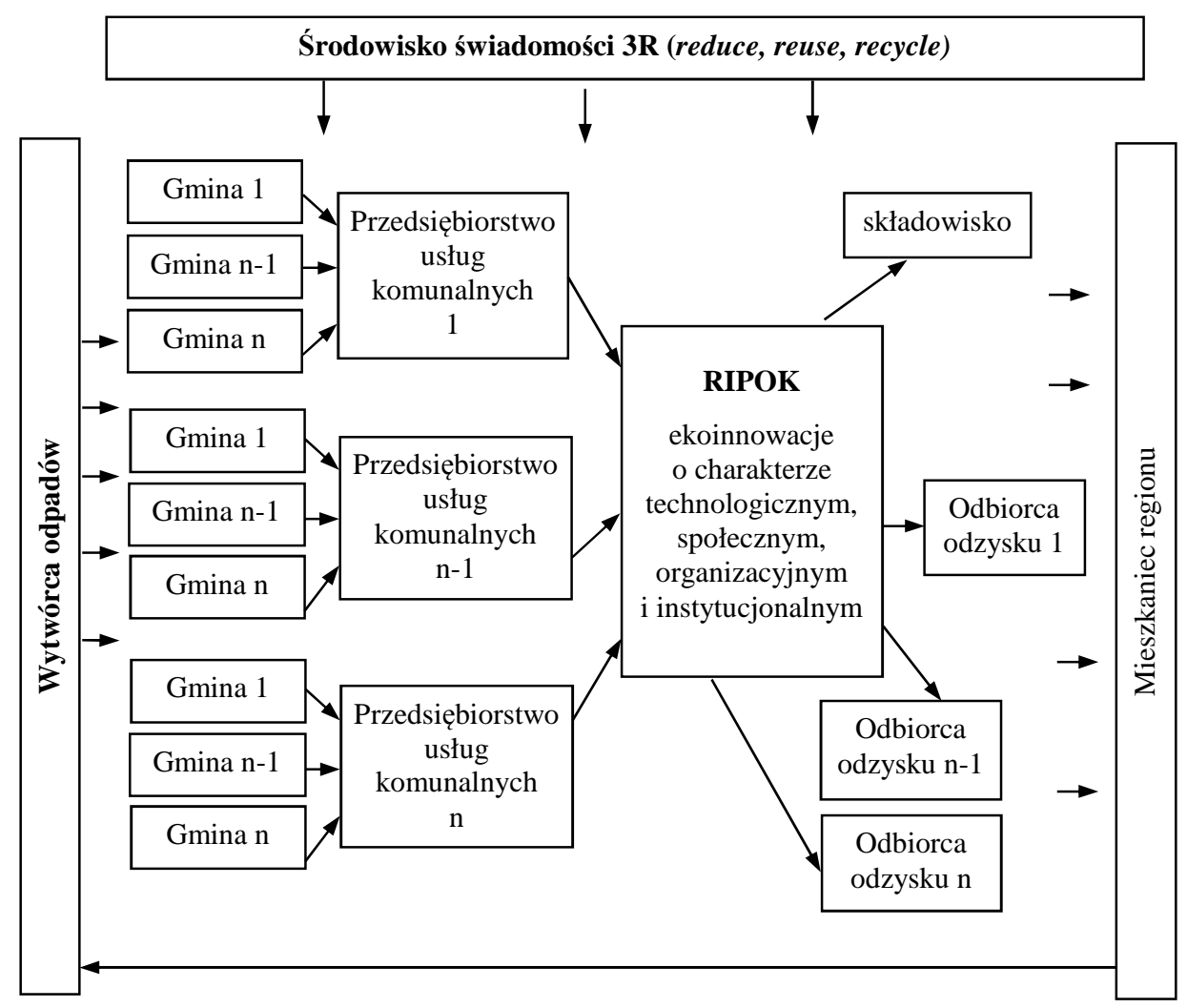

Rys. 4. Holistyczny Ekoinnowacyjny Model Biznesu podmiotów sektora gospodarki odpadami, ujęcie podmiotowe

Źródło: opracowanie własne.

\section{PODSUMOWANIE}

Funkcjonując $\mathrm{w}$ integralnych relacjach, $\mathrm{z}$ dominującą pozycją podmiotu o statusie RIPOK, dysponenta kluczowych zasobów i sposobów zarządzania nimi, badane podmioty sektora gospodarki odpadami, wpisują realizowany model biznesu w koncepcję zrównoważonego rozwoju. W ramach realizowanego holistycznego, ekoinnowacyjnego modelu biznesu, w strukturach relacji pomiędzy podmiotami, w środowisku etyki międzypokoleniowej, ekonomii umiaru, ekoświadomości i ekoefektywności, firmy realizują zasady koncepcji synergicznych ekowartości, marketingu integralnego, relacyjnego i społecznego w strategicznym horyzoncie działania. Ujmując zidentyfikowany i opisany model, przez pryzmat zasad koncepcji zrównoważonego rozwoju (np. 3R), zauważyć należy dualny charakter firm będących promotorami zidentyfikowanego Modelu biznesu w ujęciu pod- 
miotowym. Z jednej strony są oni bowiem realizatorami procesu tworzeniu ekowartości, z drugiej zaś są kreatorami warunków dla takich działań. Wszystkie zaangażowane w Modelu podmioty zintegrowane są na rzecz stworzenia wartości w postaci równowagi pomiędzy dobrostanem społecznym, środowiskowym i efektem ekonomicznym, w długiej perspektywie czasowej, której powodzenie zależy również od umiejętnego aktywizowania tych podmiotów, budującego świadomość ekologiczną, postawy prosumenckie i satysfakcję z zaangażowania. Model wykazuje cechy integralności w zakresie jego podsystemów, w ujęciu podmiotowym i przedmiotowym.

\section{LITERATURA}

[1] Afuah A., Business models. A Strategic Management Approach, McGraw-Hill Irwin, 2004.

[2] Gołębiowski T., Dudzik T.M., Lewandowska M., Witek-Hajduk M., Modele biznesu polskich przedsiębiorstw, Szkoła Główna Handlowa w Warszawie, Warszawa 2008.

[3] Lindgardt Z., Reeves M., Stalk G., Deimler M.S., Business Model Innovation: When the Game Gets Tough, Change the Game. The Boston Consulting Group, 2009, http://www.bcg.com/ documents/file36456.pdf (dostęp: 9.02.2014 r.).

[4] Nogalski B., Modele biznesu jako narzędzie reorientacji strategicznej przedsiębiorstw, „Master of Business Administration” 2009, nr 2.

[5] Obłój K., Tworzywo skutecznych strategii, PWE, Warszawa 2002.

[6] Osterwalder A., Pigneur Y., Business Model Generation: A Handbook for Visionaries, Game Changers, and Challengers. John Wiley \& Sons Inc. Hoboken, New Jersey 2010.

[7] Osterwalder A., Pigneur Y., Tucci C.L., Clarifying Business Models: Origin, Present and Future of the Concept, „Communications of the Association for Information Systems” 2005, vol. 15.

[8] Perry, Ch., Case Research In Marketing, “The Marketing Review” 2001, No. 1.

[9] Plan gospodarki odpadami dla województwa śląskiego 2014 - uchwała nr IV/25/1/2012 Sejmiku Województwa Śląskiego z dnia 24 sierpnia 2012 roku oraz uchwała nr V/6/21/2015 Sejmiku Województwa Śląskiego z dnia 16 marca 2015 r.

[10] Rozporządzenie Ministra Środowiska z dnia 11 września 2012 r. w sprawie mechaniczno-biologicznego przetwarzania zmieszanych odpadów komunalnych (Dz.U. z 2012 r., poz. 1052).

[11] Sztangret I., Sustainable Development Through Knowledge Management on the Example of Public Utilities Enterprise in IT Environment, "Business and Management Studies" 2016, vol. 2, no. 1, March.

[12] Ustawa z dnia 14 grudnia 2012 r. o odpadach (Dz.U. z 2013 r., poz. 21).

[13] Ustawa z dnia 15 stycznia 2015 r. o zmianie ustawy o odpadach oraz niektórych innych ustaw (Dz.U. z 2015 r., poz. 122).

[14] Ustawa z dnia 27 kwietnia 2001 r. Prawo ochrony środowiska (Dz.U. z 2001 r., nr 62, poz. 627).

[15] Żabińska, T., Żabiński L. (red.), Zarządzanie marketingowe. Koncepcje marketingu a praktyki zarzadzania. Aspekty teoretyczne i badawcze. AE w Katowicach, Katowice 2007. 


\section{ECO-INNOVATIVE BUSINESS MODELS ON THE EXAMPLE OF CHOSEN REGIONAL WASTE PROCESSING SYSTEM (RIPOK)}

Sustainable development also referred to as stable development or eco-development is a concept in economics that presumes the level and quality of life to be the level as guaranteed by civilization development in particular time. It is such a social and economic development in which the process of integration of political, economic and social activities is observed, with maintenance of natural balance and durability of elementary natural processes, for the purpose of ensuring the possibility to satisfy elementary needs of individual communities or citizens of both present and future generations. Identifying the sustainable development with eco-development and the principles of the concept of social welfare in the long term (strategic), with particular emphasis on the economic and environmental efficiency projects, it is worth to pay the attention to the implementation of these rules to the utilities sector. This problem becomes particularly important in the era of eco-development of the society and firms, where the skillful eco-management in subsystems of partners relations will foster communities of creators eco-values and commercial values. The purpose of this article is identification of innovative, holistic models of business in utility sector, that are the reaction on changes in environment of value creation. The ways of implement of the model in the prism of concept of sustainable development through knowledge management also, is very important in the eco-system of the chosen company, a regional leader in the municipal services sector and its partners, on the example of RIPOK.

Keywords: eco-innovative business model, eco-business, sustainable development, eco-model, eco-value.

\section{DOI: 10.7862/rz.2017.mmr.11}

Tekst złożono $w$ redakcji: listopad $2016 r$.

Przyjęto do druku: marzec 2017 r. 